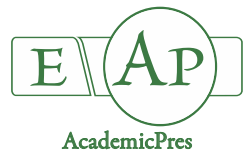

\title{
Effect of Maturation Degree on the Fixed Oil Chemical Composition, Phenolic Compounds, Mineral Nutrients and Antioxidant Properties of Pistacia lentiscus L. Fruits
}

\author{
Kaissa BOUDIEB*, Sabrina AIT SLIMANE-AIT KAKI, \\ Hayet AMELLAL-CHIBANE \\ University of M'hamed Bougara of Boumerdes, Faculty of Natural Sciences, Laboratory of Soft Technology, Valorization, \\ Physical-Chemistry of Biological Materials and Biodiversity, 35000, Boumerdes, Algeria; b.kaissa@univ-boumerdes.dz ("corresponding author); \\ aitkaki_sabrina@yahoo.fr; chibane_hayet@yahoo.fr
}

\begin{abstract}
This study aimed to evaluate the maturity stage effects on the bioactive metabolites content, the antioxidant activity and color variation of Algerian Pistacia lentiscus L. fruit. For this propose, both red and black fruits of the selected species representing two different maturation stages immature and mature, respectively are chosen. Our experimental study was initiated by a GC/MS analysis in order to determinate the fixed oils chemical composition. An AAS for macroelements and ICP-MS for microelements was carried out to evaluate the mineral composition. Furthermore, phenolic, anthocyanins and total sugars compounds level were determinate. Also, a chromameter was used to detect the color changes of fruits powders. At last, antioxidant activities were evaluated by DPPH and FRAP assays. As a result, the fixed oil qualitative evaluation, revealed new molecules were synthesized in the mature fruit oil which gives it a higher quality than one of the immature stage, we also noted that the accumulation of the oils increases with the fruits maturation while the sugar content decreases significantly. In addition, the results obtained showed that the bioactive molecules were found to be significantly high at the mature stage and its affects positively the $P$. lentiscus antioxidant activity. High levels of minerals ( $\mathrm{Ca}, \mathrm{Mg}, \mathrm{Mn}, \mathrm{Cu}$ and $\mathrm{Zn}$ ) observed in mature fruits ensure a high nutritional quality compared to immature ones. To conclude, the phytocomponents of $P$. lentiscus fruit are accumulated during maturation, which provides it with an important qualitative and quantitative value in terms of both curative and/ or nutritional fields.
\end{abstract}

Keywords: antioxidant activity; bioactive metabolits; fixed oil; maturity stage; mineral nutrients; Pistacia lentiscus L.

\section{Introduction}

Belongs to the Anacardiaceae family, Pistacia lentiscus L., commonly known as lentisk or mastic tree is member of the aromatic species, growing wild in several Mediterranean regions. It is termophilous evergreen shrub, which can reach three meters in height and producing red globose berries in clusters that turn black as they ripen (Iserin et al., 2001; Bozorgi et al., 2013; Llorens Molina et al., 2015). Their areal parts have been well used for a long time ago as remedies for various diseases such as eczema, asthma, hypertension, peptic ulcer, diarrheic, inflammation and infections (Longo et al., 2007; Djenane et al., 2011). In addition to their therapeutic effects the plant is also used in the agri-food sector (Bampouli et al., 2015).

Last years, several studies have been interested on the various uses of $P$. lentiscus fruits, galls, resin and leaves in which the obtained extracts of these different parts showed both in vivo and in vitro biological activities like antiatherogenic, anti-inflammatory, antioxidant, antimicrobial, hypotensive, anticancer, antiarthritis and antigout, treatment of wound, antiasthmatic and anthelmitic activity (Nahida et al., 2012).

According to the same studies, all these activities are related to the bioactive phytochemicals compounds especially phenolic ones (Martinez et al., 2017).

Actually, phenolic compounds regrouped the largest range of phytochemicals known as a powerful natural antioxidants and antimicrobial agents (Bampouli et al., 2015; Martinez et al., 2017).

In fact, several factors can affect the plant's chemical composition qualitatively and quantitatively (Rallo et al., 2018), among others development stage, climatic condition and both harvest region and period (Vicente et al., 2009). Meanwhile, it is known that numerous physical chemical 
and biochemical changes occur during ripening of the fruits (Seraglio et al., 2017), including color skin variation, which is considered as an important parameter for nutritional quality evaluation (Xiao et al., 2018), maturity fruit detection, mineral (Seraglio et al., 2017), chemicals and fatty acids composition (Hosni et al., 2011).

To our knowledge, the relationship between Pistacia lentiscus L. maturity stage and both their qualitative and quantitative composition as well as antioxidant activity have not been established yet.

Therefore, this study was carried out which initiated by a GC-MS qualitative analysis, followed by a determination of bioactive metabolites contents and a comparison of powder fruits color. At the same, an evaluation of macro and microelements was carried out. Our study is over by an evaluation of the methanolic fruit extracts antioxidant capacity using two techniques DPPH and FRAP.

\section{Materials and Methods}

\section{Plantmaterial}

Pistacia lentiscus L. plant fruits were collected during December 2015, from Dellys (region of Northern Algeria ; latitude $36^{\prime} 55^{\circ}(\mathrm{N})$, longitude $03^{\prime} 57^{\circ}(\mathrm{E})$, altitude 08). Peel color was used as criteria to assure the immature (red) and mature (black) fruits, which were chosen for this study (Fig. $1)$. The collected fruits were manually separated and airdried at room temperature, and finally they grounded and stored in glass bottles in cool, dry and dark place until used.

\section{Extraction procedure}

The extraction of phenolic components was performed on the delipid residues obtained after cold extraction of the fixed oils contained in P. lentiscus fruits, passing through the following steps:

\section{Oil extraction}

The oil contained in the fruit was extracted in triplicate according to the method presented by Rombaut (2013). Dry powder of immature and mature fruits, previously ground, was separately homogenized with hexane in ratio of 1:10 (w/v) and stored at ambient temperature for 2 hours with magnetic agitation. The mixture was filtered to separate the residues using Whatman No. 1 paper. The solvent was then removed using the rotary evaporator (RE $300 \mathrm{P}$, Stuart, United Kingdom) at $40{ }^{\circ} \mathrm{C}$ and the weight of the extract was measured to determine the lipid content in the plant material. The chemical composition of the fixed oil was identified by GC/MS.

\section{Methanolic extract}

Dried fat-free powder of red and black P. lentiscus fruit $(5 \mathrm{~g})$ was extracted in triplicate with $100 \mathrm{ml}$ of methanol $99.7 \%$ and the mixture was shaken for 24 hours at ambient temperature. The extract was filtered, and the solvent was removed from the sample using a rotary evaporator at $40^{\circ} \mathrm{C}$, dry extracts obtained were weighted and the percentage of crude was calculated. The samples were then stored at $4^{\circ} \mathrm{C}$, for use in further studies.
GC-MS analysis

Fatty acid compounds were analyzed on an Agilent 7820 A gas chromatography system coupled to Agilent 5975 series quadrupole mass spectrometer working in EI mode and resolved on a Termo HP-5MS column $(30 \mathrm{~m} \times 250 \mu \mathrm{m}$ $\times 0.25 \mu \mathrm{m})(\mathrm{J} \& \mathrm{~W}$ Scientific, USA). Compounds were desorbed at $260{ }^{\circ} \mathrm{C}$ injection port. Analysis was performed in programmed temperature : $50{ }^{\circ} \mathrm{C}$ for $5 \mathrm{~min}$, then $(50$ $250^{\circ} \mathrm{C}$ ) over $25 \mathrm{~min}$, then $250^{\circ} \mathrm{C}$ for 5 min using Helium as a carrier gas with a flow of $1.2 \mathrm{ml} / \mathrm{min}$. Gas chromatography/mass spectrometry (GC/MS) interface temperature was set to $280^{\circ} \mathrm{C}$. Compounds were identified using NIST 11 library of mass spectra on Agilent Chemstation software.

\section{Total phenolic contents (TPC)}

TPCs of methanolic extracts of immature (MER) and mature (MEB) lentisck fruits were established using the Folin-Ciocalteu colorimetric assay as described in Singleton and Rossi's (1965) method. $200 \mu \mathrm{l}$ for each extract was introduced into a test tube; the mixture $(1 \mathrm{ml}$ of Folin Ciocalteu diluted 10 times and $0.8 \mathrm{ml}$ of sodium carbonate 7.5\%) was added. The tubes were shaken and kept for 30 minutes at dark. The absorbance was then read at $765 \mathrm{~nm}$ using the UV / Vis spectrophotometer (Optizen Pop, Mecasys Co. Ltd., Daejeon, Korea). A calibration curve with a different concentration of gallic acid was prepared. The results were expressed as gallic acid (mg) equivalents per gram (g) of dry extract.

\section{Determination of total anthocyanins (ANCs)}

Total anthocyanins (ANCs) were measured by the $\mathrm{pH}$ differential method according to Giusti and Wrolstad (2001). The dried powder of red and black $P$. lentiscus fruit $(1 \mathrm{~g})$ was extracted with $20 \mathrm{ml} \mathrm{HCl}$-methanol $(1 \%, \mathrm{v} / \mathrm{v})$ for $2 \mathrm{~h}$. Extracts were homogenized thoroughly with $0.025 \mathrm{M}$ potassium chloride $\mathrm{pH} 1$ buffer and similarly with sodium acetate buffer $\mathrm{pH} 4.5$ in 1:10 ratio of extract to buffer. The absorbance of these solutions was obtained at 520 and 700 $\mathrm{nm}$, by using UV-visible spectrophotometer. The absorbance of the diluted sample (A) was calculated as follow:

$$
\mathrm{A}=\left(\mathrm{A}_{520}-\mathrm{A}_{700}\right) \mathrm{pH} 1.0-\left(\mathrm{A}_{520}-\mathrm{A}_{700}\right) \mathrm{pH} 4
$$

The anthocyanin monomeric pigment content in the initial sample was calculated using the formula below:

Anthocyanin content $(\mathrm{mg} /$ liter $)=(\mathrm{A} \times \mathrm{MW} \times \mathrm{DF} \times$ $1000) /(\varepsilon \times 1)$ $(\mathrm{g} / \mathrm{mol})$

MW: molecular weight for cyanidin 3-glucoside $=449.2$

$\varepsilon:$ is the molar absorptivity of cyanidin 3-glucoside $=$ 26,900 (g/mol), and DF the dilution factor. Anthocyanin content was expressed as milligrams of cyanidin 3-glucoside (cy-3-glu) equivalents per grams of dry weight (dw) of the triplicate extracts.

\section{Evaluation of antioxidant activity by Diphenyl-Picryl-} Hydrazyl tests (DPPH)

Antioxidant activity was measured by the DPPH method assay (1, 1-diphenyl-2-picrylhydrazyl) according to the protocol described by Sanchez-Moreno (2002). $50 \mu \mathrm{l}$ of the immature and mature fruits extract at different 
838

concentrations were added to $1950 \mu \mathrm{l}$ of DPPH methanolic solution $(0,0025 \mathrm{~g} / \mathrm{ml})$. After vortexing, the mixture was stored in the dark for 30 minutes and the optical density was measured at $515 \mathrm{~nm}$. Control contains only the DPPH solution and the positive control was represented by standard antioxidant solutions; ascorbic acid absorbance was measured under the same conditions as the test sample. Antioxidant activity was estimated as percent inhibition or percentage of antioxidant activity, according to the following formula: $\times 100$ )

$\%$ Antioxidant activity $=\left(\mathrm{Abs}_{\text {control }}-\mathrm{Abs}_{\text {test }}\right) /\left(\mathrm{Abs}_{\text {control }}\right.$

Where, Abs is the absorbance at the wavelength of 515 $\mathrm{nm}$. The concentration in $\mathrm{mg}$ of dry extract per $\mathrm{ml}$ of solvent $(\mathrm{mg} / \mathrm{ml})$ that inhibits the formation of $\mathrm{DPPH}$ radicals by $50 \%$ is defined as $\mathrm{IC}_{50}$ value.

\section{Ferric reducing antioxidant power (FRAP)}

The reducing power of immature and mature fruits extract has been determined according to the Yen and Chen (1995) method. In test tubes containing $1 \mathrm{ml}$ of sample solution at different concentrations diluted in distilled water, were added $2.5 \mathrm{ml}$ of phosphate buffer $(0.2 \mathrm{M}, \mathrm{pH}$ 6.6) and $2.5 \mathrm{ml}$ of potassium hexacyanoferrate $\left[\mathrm{K}_{3} \mathrm{Fe}\right.$ $\left.(\mathrm{CN})_{6}\right]$ at $1 \%$ in distilled water. The mixture was incubated at $50{ }^{\circ} \mathrm{C}$ for 20 minutes. A volume of $2.5 \mathrm{ml}$ of trichloroacetic acid (10\%) was then added and the mixture was centrifuged at $3000 \mathrm{rpm}$ for $10 \mathrm{~min}$. The supernatant $(2.5 \mathrm{ml})$ was mixed with $2.5 \mathrm{ml}$ of distilled water and $0.5 \mathrm{ml}$ of $\mathrm{FeCl}_{3}(1 \%)$ freshly prepared. A blank without sample was prepared under the same conditions. The reading was made at $700 \mathrm{~nm}$. In this method, increased absorbance of the reaction mixture means increased reducing power.

\section{Colormeasurement}

The color of dry powders of immature and mature $P$. lentiscus fruits was measured, using a Chromameter (Model Chromameter, Konica Minolta, Osaka, Japan) and the data were expressed in $L^{*}$ (lightness), $a^{*}$ (redness-greenness) and $b^{*}$ (yellowness-blueness) values. The color reading was taken three times. $a^{*}$ and $b^{*}$ values were used to calculate chroma $\left(C^{*}=\left[a^{* 2}+b^{* 2}\right]^{1 / 2}\right)$, and hue angle $\left(H^{\circ}=\right.$ arctangent $b^{*} /$ $\left.a^{*}\right)\left(0^{\circ}\right.$ : red-purple, $90^{\circ}$ : yellow, $180^{\circ}$ : bluish-green, $270^{\circ}$ : blue) (McGuire, 1992).

\section{Total sugar content}

The total sugar content was determined by colorimetric assay using the phenol-sulphuric acid method (Dubois et al., 1956). The two samples of immature and mature fruit powder placed in glass tubes $(10 \mathrm{~g})$ were extracted with distilled water in a water bath at $85^{\circ} \mathrm{C}$ for 2 hours. The tubes were then centrifuged at $4000 \mathrm{rpm}$ for 10 minutes. The supernatant contains the total sugar mixture to be measured. The determination was made from $0.5 \mathrm{ml}$ of extract to which $0.5 \mathrm{ml}$ of $5 \%$ aqueous phenol solution and $2 \mathrm{ml}$ of $98 \%$ concentrated sulphuric acid were added. After vortex homogenization, the tubes were placed in a water bath at $90{ }^{\circ} \mathrm{C}$ for 5 minutes, then stored in the dark for 30 minutes to cool the mixture before reading the absorbance of the solution to the spectrophotometer at $492 \mathrm{~nm}$, the blank consists of $0.5 \mathrm{ml}$ of water to which all the assay reagents have been added. The quantification of total sugars was performed by a calibration curve with different concentrations of glucose solution at $1 \mathrm{~g} / \mathrm{l}$.

\section{Mineral composition}

The mineral constituents ( $\mathrm{Ca}, \mathrm{Na}, \mathrm{K}$, et $\mathrm{Mg}$ ) present in lentisk fruits were analysed, using an atomic absorption spectrometry (Zeenit $700 \mathrm{P}$ is based on the Zeeman technique. It covers both flame AAS and graphite furnace AAS, Germany). An inductively coupled plasmamass spectrometry Agilent 7700 ICP-MS systems has been employed for trace element determination (Fe, Mn, Cr, Co, $\mathrm{Cu}, \mathrm{Zn}, \mathrm{Ni}, \mathrm{Cd}, \mathrm{Pb}$ and $\mathrm{As}$ ). Samples used were mineralized by dry ashing in a muffle furnace at $550^{\circ} \mathrm{C}$ until a white ash of constant weight was obtained, than the yield of minerals was calculated and the dissolved samples in hydrochloric acid were used to estimate their mineral content.

\section{Statistical analysis}

All analyses were performed in triplicate and results are expressed as average values with standard deviation ( \pm SD). Analysis of Variance (One-way ANOVA), followed by Tukey's HSD Test was carried out to determine significant group differences $(\mathrm{p}<0.05)$ between means, using Statistica 7.1 (StatSoft Inc, France).

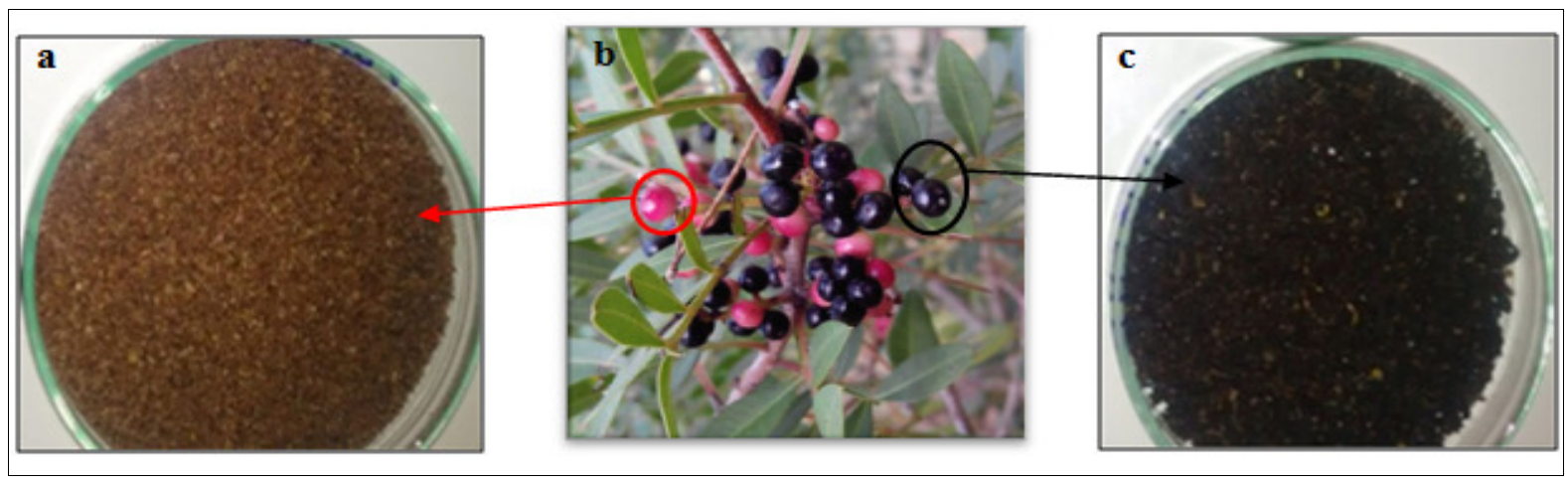

Fig. 1. Plant material: Pistacia lentiscus L. fruits and dry powders. a: dry powder of red fruit, b: red and black fruits of $P$. lentiscus, c: dry powder of black fruit 


\section{Results and Discussion}

The yields of fixed oil, phenolic extract, ash and total sugars from immature and mature fruits are summarized in the Table 1.

Total lipid content and GC-MS analysis of the fixed oil

The yield of fixed oils extracted from $P$. lentiscus varied from $11.25 \%$ for immature fruits (red) to $32.18 \%$ for mature fruits (black) as shown in Table1. Total lipid accumulation showed an increasing trend as maturity progressed. In good agreement with our results, Charef et al. (2008) reported that the crude fat level of the P. lentiscus fruit was found to differ from $32.8 \%$ for black fruits to $11.70 \%$ for red fruits. The transition of the fruit from the immature (green) to mature (red) was characterized by a significant increase in total lipid contents of Schinus molle L. fruit as reported by Hosni et al. (2011).

Fatty acids compounds of immature and mature fruit of $P$. lentiscus fruits, were identified through mass spectrometry attached with GC and the active principles with their retention time (RT), Kovat's index (KI), Library Score (LS), nature of compounds, molecular formula and molecular weight (MW) are summarized in the Table 2. Chromatograms of the both extracts were represented in the Figs. 3 and 4.

Analysis of phytochemical composition of the both oil extracts by gas chromatography-mass spectrometry (GCMS) revealed the presence of various compounds such as saturated fatty acid, mono and polyunsaturated fatty acid, triterpènes, phytosterols, steroids, phenolic lipids and alcoholic compounds.

Fourteen (14) phytoconstituents were identified in hexane extract of immature fruits and 21 components were identified in hexane extract of mature fruits. In addition to the volatile compounds of red fruit and except of oleic acid3-hydroxypropyl ester: fatty acid ester, eight new constituents have been produced at the mature stage (Table 2). Such as squalene, an important natural polyunsaturated triterpene, intermediate metabolite in the synthesis of cholesterol, steroid hormones and vitamin $\mathrm{E}$ and $\mathrm{D}$ in vivo in humans and animals. Furthermore, it exhibited an antioxidant, anti-bacteria and antifungal function (Hataminia et al., 2018). On the other hand, squalene directly influences the stability of oil, and its chain-breaking ability contributes to the regeneration of $\alpha$-tocopherol (Rallo et al., 2018). This probably explains its appearance in the mature stage in the form of $\alpha$-Tocopherol acetate. As reported by Pereira et al. (2015), $\alpha$-Tocopherol acetate is the result of esterification of $\alpha$-Tocopherol, this process improves its stability, and when in contact with the skin, its hydrolysis exposes the phenolic hydroxyl part of $\alpha$ Tocopherol; the most common component in vitamin $\mathrm{E}$, which is the functional and active group responsible for the antioxidant activity.

Ethyl iso-allocholate, another Steroid identified in the oil of black fruit, known by its antimicrobial, antiinflammatory, anticancer, antiasthma and diuretic activities (Daffodil et al., 2012). 3-acetoxy-7, 8-epoxylanostan-11-ol a terpene alchohol, among the detected compounds at the mature stage of fruit, as reported in previous study, had antiinflammatory and antimicrobial properties (Zekeya et al., 2014). Methyl-Z-5, 11, 14, 17-eicosatetraenoate, $Z$, Z-9hexadecenoic acid-9-hexadecenyl ester and Arachidic acid, are Methyl ester, unsaturated fatty acid ester and saturated fatty acid compound, respectively, were also determined in oil extract for mature fruit.

Furthermore, among the similar compounds detected in the both extract; palmitic acid (C16:0) a saturated fatty acid, which if it is combined with linoliec acid, decrease cholesterol levels in blood. This is significant because linoliec acid (18:2); polyunsaturated omega-6 fatty acid, is always found with palmitic acid in olive, palm and coconut oils as reported by French et al. (2002). This observation was also supported by our data on immature and mature lentisk fruit oil.

Oleic acid (C18:1), a mono-unsaturated omega-9 fatty acid also determined in both extract. Its content level as indicated in the GC-MS chromatogram (Figs. 2 and 3), increased with maturate stage. It is also noted that the high amount of oleic acid corresponds to low level of linoleic however opposite trend was observed of the oil for mature fruits. Oil extracted from red and black fruit samples is relatively rich in phytosterol like $\beta$-sitosterol. These findings were in agreement with those indicated by Trabelsi et al. (2012) in his study about the sterols at the different stages of maturation in $P$. lentiscus. Lupeol, another triterpene were synthesizes during the ripening process, Lupeol has been shown to exhibit beneficial activity against inflammation, cancer, arthritis, diabetes, heart diseases, renal toxicity and hepatic toxicity (Saleem, 2009). Nevertheless, this type of compounds is not reported in P. lentiscus aerial parts in the majority of previous studies.

\section{Determination of total phenolic content and anthocyanin}

Extraction yield of phenolic components of $P$. lentiscus, ranged from $18.28-23.64 \%$ for immature to mature fruits (Table 1), while TPC increased from 252.38 to $503.87 \mathrm{mg}$ of gallic acid equivalents/g of dry extract in immature and mature stage, respectively (Table 2 ). These results showed that TPC of methanolic extracts of lentisk fruits was strongly affected by maturity stages.

Table 1. Composition of some bioactive content of P. lentiscus fruits at both maturity stages

\begin{tabular}{|c|c|c|c|c|c|}
\hline & \multicolumn{2}{|c|}{ Immature fruits } & \multicolumn{2}{|c|}{ Mature fruits } & \multirow{2}{*}{$\mathrm{p}$} \\
\hline & Means & $\pm \mathrm{SD}$ & Means & $\pm \mathrm{SD}$ & \\
\hline Oil yield (\%) & $11,25^{b}$ & 2.27 & $32,18^{a}$ & 1.87 & $<0.01$ \\
\hline Phenolic extract (\%) & $18.28^{b}$ & 0.81 & $23.64^{a}$ & 1.10 & $<0.01$ \\
\hline Total sugars ( $\mathrm{mg} / 100 \mathrm{~g} \mathrm{dw})$ & $5.63^{\mathrm{a}}$ & 0.41 & $3.33^{\mathrm{b}}$ & 0.03 & $<0.01$ \\
\hline Ash (\%) & $3,68^{a}$ & 0.017 & $2,98^{b}$ & 0.169 & $<0.05$ \\
\hline
\end{tabular}

SD: standard deviation, dw: dry weight; a-b: different letters indicate differences between means in the same row according to Tukey test at $\mathrm{p}<0.05$. 
840

Table 2. Gas chromatography coupled to mass spectroscopy (GC-MS) results of the fatty acids composition identified in the fixed oil of immature and mature $P$. lentiscus fruits

\begin{tabular}{|c|c|c|c|c|c|c|c|c|}
\hline Compound & RT & KI & LS & $\begin{array}{l}\text { Compound } \\
\text { nature }\end{array}$ & $\begin{array}{l}\text { Molecular } \\
\text { formula }\end{array}$ & $\begin{array}{c}\text { Molecular } \\
\text { weight }(\mathrm{g} / \mathrm{mol})\end{array}$ & $\begin{array}{c}\text { Red fruit } \\
\text { oil }\end{array}$ & $\begin{array}{c}\text { Black fruit } \\
\text { oil }\end{array}$ \\
\hline Palmitic acid & 26.63 & 1942 & 88.7 & Saturated fatty acid (C16:0) & $\mathrm{C}_{16} \mathrm{H}_{32} \mathrm{O}_{12}$ & 256.43 & + & + \\
\hline $5 \alpha, 17 \alpha$-pregnan-20-one & 29.70 & 2065 & 93.0 & Steroid & / & / & + & + \\
\hline $5 \alpha$-16, 16-dimethyl-androstan-17-one & 30.01 & 2075 & 87.8 & Steroid & $\mathrm{C}_{21} \mathrm{H}_{34} \mathrm{O}$ & 302.505 & + & + \\
\hline Linoleic acid & 32.22 & 2095 & 90.7 & $\begin{array}{l}\text { polyunsaturated omega- } 6 \\
\text { fatty acid }(\mathrm{C} 18: 2)\end{array}$ & $\mathrm{C}_{18} \mathrm{H}_{32} \mathrm{O}_{2}$ & 280.452 & + & + \\
\hline Oleic acid & 32.42 & 2113 & 86.9 & $\begin{array}{l}\text { monounsaturated omega- } 9 \\
\text { fatty acid }(\mathrm{C} 18: 1)\end{array}$ & $\mathrm{C}_{18} \mathrm{H}_{34} \mathrm{O}_{2}$ & 282.47 & + & + \\
\hline Oleic acid-3-hydroxypropyl ester & 35.28 & 2154 & 91.4 & Fatty acid ester & $\mathrm{C}_{21} \mathrm{H}_{40} \mathrm{O}_{3}$ & 340.548 & + & - \\
\hline 3-hydroxy-3a, $5 \alpha$-androstane-11, 17-dione & 35.47 & 2300 & 88.9 & Steroid & $\mathrm{C}_{19} \mathrm{H}_{26} \mathrm{O}_{3}$ & 302.414 & + & + \\
\hline Methyl-Z-5,11,14,17-eicosatetraenoate & 35.61 & 2308 & 92.7 & Methyl ester & $\mathrm{C}_{21} \mathrm{H}_{34} \mathrm{O}_{2}$ & 318.501 & - & + \\
\hline Methyl lambertianate & 35.80 & 2325 & 90.5 & Methyl ester & $\mathrm{C}_{21} \mathrm{H}_{30} \mathrm{O}_{3}$ & 330.468 & + & + \\
\hline Arachidic acid & 38.19 & 2359 & 88.7 & Saturated fatty acid (C20:0) & $\mathrm{C}_{20} \mathrm{H}_{40} \mathrm{O}_{2}$ & 312.538 & - & + \\
\hline Butyl-9,12,15-octadecatrienoate & 38.28 & 2399 & 87.9 & fatty acid butyl ester & $\mathrm{C}_{22} \mathrm{H}_{38} \mathrm{O}_{2}$ & 334.544 & + & + \\
\hline Pentadecylphenol & 38.40 & 2406 & 94.3 & phenolic lipid & $\mathrm{C}_{21} \mathrm{H}_{36} \mathrm{O}$ & 304.518 & + & + \\
\hline Palmitic acid- $\alpha$-monoglyceride & 38.60 & 2482 & 91.5 & Saturated fatty acid (C16:0) & $\mathrm{C}_{16} \mathrm{H}_{32} \mathrm{O}_{2}$ & 256.43 & + & + \\
\hline 11,13-Eicosadienoic acid methyl ester & 38.70 & 2583 & 89.9 & $\begin{array}{l}\text { Unsaturated fatty acid ester } \\
\qquad(\mathrm{C} 20: 2)\end{array}$ & $\mathrm{C}_{21} \mathrm{H}_{38} \mathrm{O}_{2}$ & 322.533 & + & + \\
\hline Squalene & 39.50 & 2914 & 89.6 & Triterpene & $\mathrm{C}_{30} \mathrm{H}_{50}$ & 410.718 & - & + \\
\hline Methyl cholate & 40.45 & 2995 & 97.1 & $\begin{array}{l}\text { Salt derived from cholan } \\
\text { steroid }\end{array}$ & $\mathrm{C}_{25} \mathrm{H}_{42} \mathrm{O}_{5}$ & 422.606 & - & + \\
\hline Ethyl iso-allocholate & 42.07 & 3094 & 98.5 & Steroid derivative & $\mathrm{C}_{26} \mathrm{H}_{44} \mathrm{O}_{5}$ & 436.633 & - & + \\
\hline$\alpha$-Tocopherol acetate & 44.45 & 3154 & 90.6 & Alcohol tocopherol & $\mathrm{C}_{31} \mathrm{H}_{52} \mathrm{O}_{3}$ & 472.754 & - & + \\
\hline$\beta$-sitosterol & 46.66 & 3173 & 95.6 & Phytosterol & $\mathrm{C}_{29} \mathrm{H}_{50} \mathrm{O}$ & 414.706 & + & + \\
\hline Lupeol & 47.62 & 3270 & 98.0 & Triterpene & $\mathrm{C}_{30} \mathrm{H}_{50} \mathrm{O}$ & 426.729 & + & + \\
\hline 3-acetoxy-7,8-epoxylanostan-11-ol & 48.50 & 3295 & 90.2 & Alcoholic compound & $\mathrm{C}_{32} \mathrm{H}_{54} \mathrm{O}_{4}$ & 502.768 & - & + \\
\hline $\begin{array}{c}\text { Z,Z-9-hexadecenoic acid-9-hexadecenyl } \\
\text { ester }\end{array}$ & 51.43 & 3385 & 86.9 & Unsaturated fatty acid ester & $\mathrm{C}_{34} \mathrm{H}_{64} \mathrm{O}_{2}$ & 504.87 & - & + \\
\hline
\end{tabular}

RT: retention time, KI: kovat's index, LS: library score; + : presence, - : absence of the molecule.

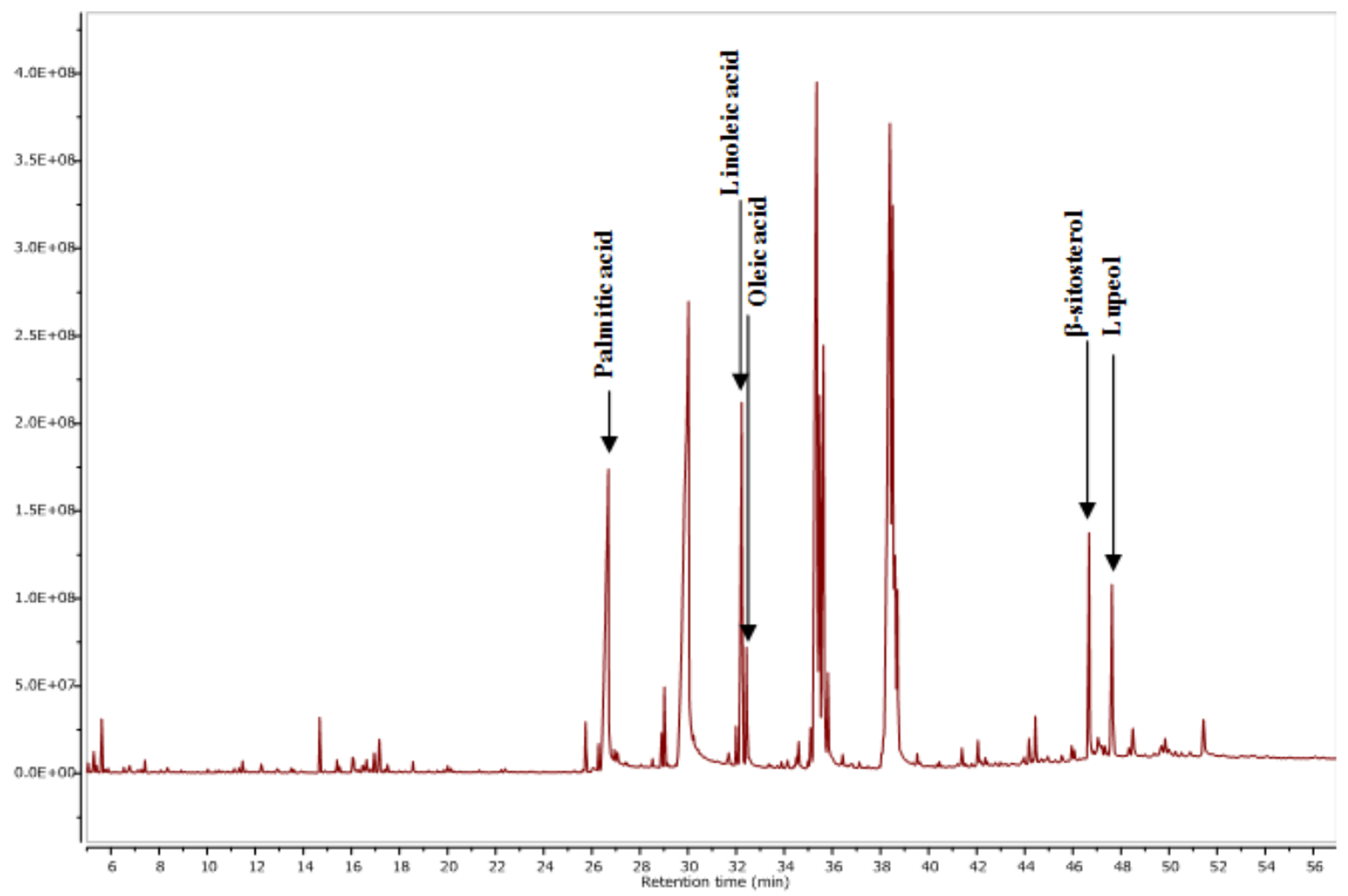

Fig. 2. GC-MS chromatogram of immature $P$. lentiscus fruits oil extract 


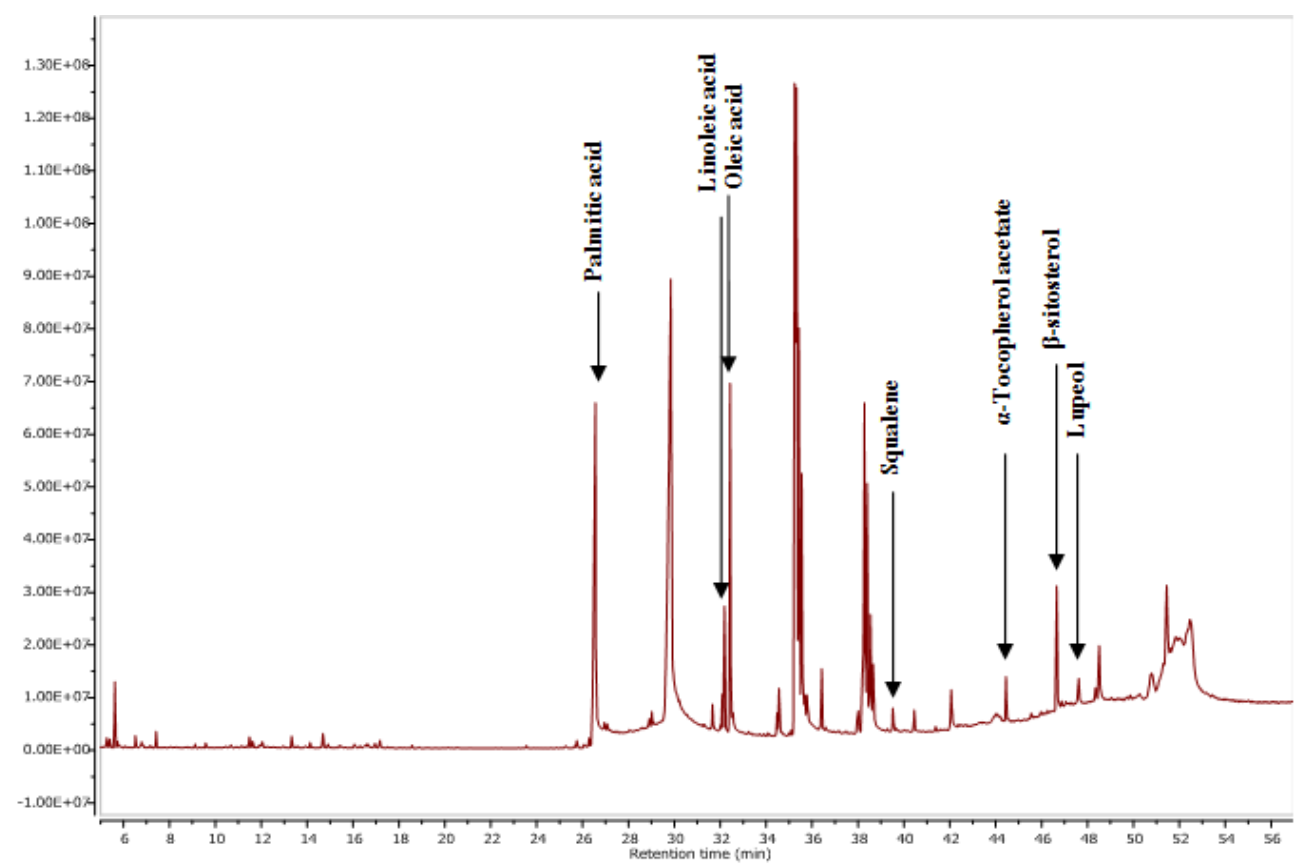

Fig. 3. GC-MS chromatogram of mature P. lentiscus fruits oil extract

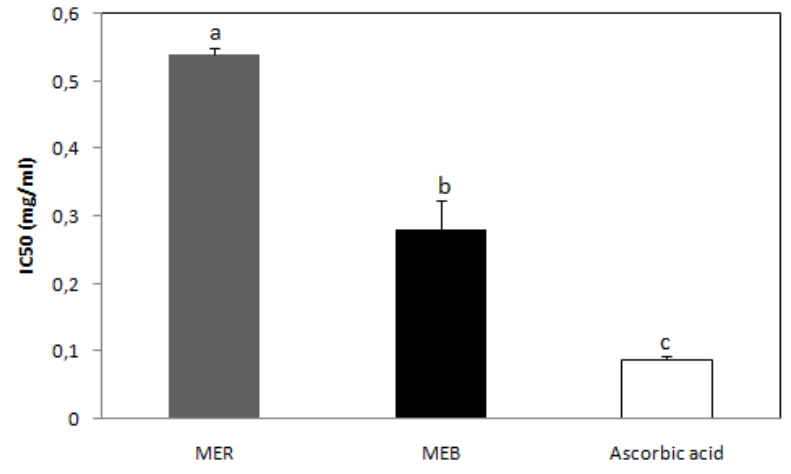

Fig. 4. $\mathrm{IC}_{50}$ values of immature and mature $P$. lentiscus fruits methanolic extracts. $\mathrm{IC}_{50}$ : half-maximal inhibitory concentration; MER: methanolic extract of red fruits, MEB: methanolic extract of black fruits; a-c: different letters indicate differences between means according to Tukey test at $p<0.05$

In a study examining the effect of maturity on phenolics of cherry fruits (Prunus avium L.), it was noted that TPC increased for un-ripened to fully -ripened stage (Mahmood et al., 2013). Our results were also according with those reported by Shin et al. (2015) in Cudrania tricuspidata extract, where the hight level of total phenolic contents was shown at the fully mature stage. Xiaoa et al. (2018) investigated the concentration of the total free phenolic content in two varieties of grape at five ripening stages and found that the concentration to sharply increase from the veraison stage to the ripe stage. Total phenolic compounds decreased during the early stages of sweet cherry development but exponentially increased from the stage that coincided with the anthocyanin accumulation and fruit darkening (Serrano et al., 2005). As shown by Mahmood et al. (2013), red fruits accumulate antocyanins and flavonols during maturity, which explains the high content of polyphenols.

(ANCs) are flavonoid pigments, which are responsible for the red, blue, purple, and violet colors of fruit (Martinez et al., 2017; Chaves-Silva et al., 2018). ANCs are unique among flavonoids as their structures reversibly undergo $\mathrm{pH}$ dependent transformation in aqueous solution. At a $\mathrm{pH}$ below two, anthocyanins exist predominantly in the red flavylium cation form and colorless after rapid hydratation of the flavylium cation at $\mathrm{pH}$ values ranging from 3 to 6 ( $\mathrm{He}$ and Giusti, 2010).

As shown in Table 3, ANCs of P. lentiscus varied significantly as maturity progressed $(\mathrm{p}<0.05)$. The highest anthocyanin content was obtained in black fruits with 3.75 mg cyanidin-3-glucoside eq/g of dry powder, while the lowest content was observed in red fruits with $0.2 \mathrm{mg}$ cyanidin-3-glucoside eq/g of dry powder. These findings are in agreement with previous studies reporting that anthocyanin accumulation in sweet cherries increased during fruit development and correlated positively with abscisic acid levels, which is responsible for regulating the expression of anthocyanin biosynthesis genes (Teribia et al., 2016). ANCs content in dark brown berries of black currants increased by a factor of 4.0 to 4.6 times its level in reddish berries (Rubinskiene et al., 2006). An exponential increase in total anthocyanins was also observed in sweet cherries with low concentrations in the early stages, and a sharp increase in later stages of maturation (Serrano et al., 2005). ANCs levels, as reported by Akond et al. (2011), were directly related to the color of the bean tegument; the black colored bean contained the highest anthocyanin content than the white or yellow one. The same finding was obtained in another study, where anthocyanins were not detected in the light-colored seed cultivar of BRS Xiquexique (Moreira-Araujo et al., 2018). 
Table 3. Determination of total phenols and anthocyanins of immature and mature $P$. lentiscus methanolic extract

\begin{tabular}{|c|c|c|c|c|c|}
\hline & \multicolumn{2}{|c|}{ Immature fruits } & \multicolumn{2}{|c|}{ Mature fruits } & \multirow[b]{2}{*}{$\mathrm{p}$} \\
\hline & Means & $\pm \mathrm{SD}$ & Means & $\pm \mathrm{SD}$ & \\
\hline $\begin{array}{c}\text { Total phenols } \\
\text { (mg gallic acid eq/g of dry extract) }\end{array}$ & $252.38^{b}$ & 5.78 & $503.87^{a}$ & 10.46 & $<0.001$ \\
\hline $\begin{array}{c}\text { Anthocyanin } \\
\text { (mg cyanidin-3-glucoside eq/g } \\
\text { of dry powder) }\end{array}$ & $0.2^{\mathrm{b}}$ & 0.02 & $3.75^{\mathrm{a}}$ & 0.2 & $<0.01$ \\
\hline
\end{tabular}

Results for antioxidant activity

Antioxidant activity of the methanolic extracts of red (MER) and black (MEB) fruits of P. lentiscus were carried out by two chemical techniques (DPPH free radical scavenging and FRAP assay).

In this study, the antioxidant activity of the both extracts and synthetic ascorbic acid (as positive control) was determined from the half-maximal inhibitory concentration $\left(\mathrm{IC}_{50}\right)$ for scavengers; is the amount of antioxidant required to decrease the initial of 2, 2-diphenyl-1-picrylhydrazyl (DPPH) concentration by $50 \%$.

The obtained optical densities values had made it possible to calculate the percentage of antioxidant activity to plot curves (percentage of inhibition as a function of the different concentrations), having a linear or logarithmic shape. From these curves, we determined the $\mathrm{IC}_{50}$ value of each extract (Fig. 4). High $\mathrm{IC}_{50}$ values express lower reducing activity, while lowest values express greater reducing activity.

Based on the $\mathrm{IC}_{50}$ values, the data shows that the DPPH radical scavenging activity of the samples increased in the following order: MER < MEB < Ascorbic acid. With $\mathrm{IC}_{50}$ values of $0.54 \pm 0.043 \mathrm{mg} / \mathrm{ml}, 0.28 \pm 0.01 \mathrm{mg} / \mathrm{ml}$ and 0.087 $\pm 0.006 \mathrm{mg} / \mathrm{ml}$, respectively.

This essay showed that mature black fruits exhibited significantly greater antioxidant activity than the immature red fruits $(\mathrm{p}<0.05)$. However, the both extracts have a lowest antioxidant activity than the ascorbic acid. The results highlighted significant increase in DPPH scavenging activity as maturity progressed. The similar pattern of increase in DPPH radical scavenging activity in relation with ripening stage of cherry fruit has been reported by Mahmood et al. (2013). The same result was also obtained in previous study investigated the antioxidant activity in Cudrania tricuspidata at various maturity stages (Shin et al., 2015).

The antioxidant potential of MER and MEB was also evaluated through the Ferric-Reducing Antioxidant Power (FRAP assay), due to the reduction of the Ferric tripyridyltriazine, $\mathrm{Fe}^{3+}-\mathrm{TPTZ}$ complex to its ferrous form, $\mathrm{Fe}^{2+}$-TPTZ. Values of the optical densities obtained in this study, made it possible to draw curves for each methanol extract and synthetic ascorbic acid (positive control). The results presented in Fig. 5 show that the reducing power is proportional to the increase in the concentrations used.

This assay shows that the ability to reduce iron is almost the same for the MER and MEB, with a slight increase observed in mature $P$. lentiscus fruit extract. While the both extracts reveals a lower antioxidant power than the ascorbic acid.
Both analyzes suggest that mature fruit with a high content of total phenolic is a richer source of antioxidant than immature ones, whereas, the degree of fruit maturation does not have a great influence on the iron reduction capacity as on the free radicals of DPPH.

Furthermore, several studies have found a relevant correlation between the highest antioxidant properties and bioactive compounds such as phenols, tannins, anthocyanins and total flavonoid contents (Skrovankova $e t$ al., 2015; Nobre et al., 2018). Therefore, both phenolics and anthocyanins influence antioxidant activity considerably.

\section{Color analysis}

As shown in Table 4, color of lentisk fruit varied significantly during maturation. The lightness coefficient $L^{*}$, ranged from 31.5 to 35.2 for a black and red fruits, respectively. Results showed that $L^{*}$ decrease significantly as fruit ripening stage. The immature fruit had the greater luminosity value where the lower luminosity values noted in the mature one, which is distinguished by a black color of fruits. We also observed that the values of $a^{*}$ and $b^{*}$, chromaticity coordinates, decreased significantly from unripe to ripe fruit.

The $a^{*}$ or red-green values ( all values positive), where the highest for the unripe fruits (11.1), whereas the lowest values were shown by the ripe fruits (4.6), these results agree with the color of the unripe seeds, characterized by red skin. For black fruit, we suppose that the color has been masked by the yellow color of the fixed oils witch increased at this stage of ripening. The $b^{*}$ or yellow blue values, indicating the turn of the color of lentisk fruit from yellowish at the immature stage to bluer color at the mature stage. The chroma $C^{*}$, an index of color saturation or intensity, the values of chroma decreased significantly from the immature to mature stage ( $\mathrm{p}<0.05)$. Therefore, P. lentiscus fruits lose its brightness as the increasing of darkening skin color. The hue angle $H^{\circ}$ determines the red, yellow, green, blue, or intermediate colors between adjacent pairs of this basic colors, where the lower hue angle indicate a redder color, as shown by the results obtained in the fruits in two maturation stage, with $0.51^{\circ}$ for immature fruits and $0.53^{\circ}$ for mature fruits, the variation of this values was not significant between the two stages $(p>0.05)$. Similarly, to other studies, it was admitted that the change in colors during the maturation of fruits correlated with the increase of anthocyanins and total phenolic compounds, where color of the peel becomes red, yellow and/or blue (Williams and Benkeblia, 2018). 
Table 4. Change in color parameters $L^{*}, a^{*}, b^{*}, C^{*}$ and $H^{\circ}$ in both maturation stages

\begin{tabular}{|c|c|c|c|c|c|}
\hline & \multicolumn{2}{|c|}{ Immature fruits } & \multicolumn{2}{|c|}{ Mature fruits } & \multirow{2}{*}{$\mathrm{p}$} \\
\hline & Means & $\pm \mathrm{SD}$ & Means & $\pm \mathrm{SD}$ & \\
\hline$L^{*}$ & $35.2^{\mathrm{a}}$ & 0.95 & $31.5^{\mathrm{b}}$ & 0.0 & $<0.05$ \\
\hline$a^{*}$ & $11.1^{2}$ & 0.90 & $4.6^{b}$ & 0.30 & $<0.05$ \\
\hline$b^{*}$ & $6.4^{\mathrm{a}}$ & 0.90 & $2.9^{b}$ & 0.10 & $<0.05$ \\
\hline$C^{*}$ & $12.8^{\mathrm{a}}$ & 1.17 & $5.4^{\mathrm{b}}$ & 0.22 & $<0.05$ \\
\hline$H^{\circ}$ & 0.51 & 0.045 & 0.53 & 0.04 & NS \\
\hline
\end{tabular}

( blueness (yellow $b^{*}=100$ and blue $b^{*}=-100$ ), $C^{*}$ : chroma value, $H^{\circ}$ : hue angle; SD: standard deviation; a-b: different letters indicate differences between means in the same row according to Tukey test at $\mathrm{p}<0.05$; NS: not significant.

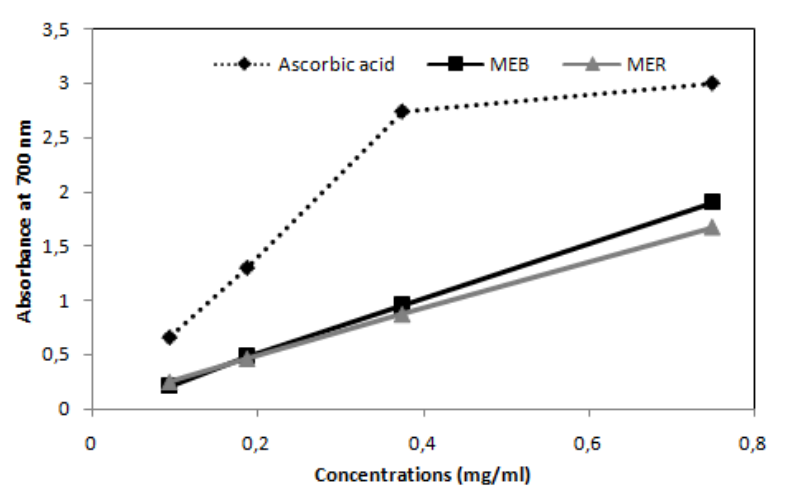

Fig. 5. Reducing power of $P$. lentiscus fruits methanolic extracts at both maturity stages. MER: methanolic extract of red fruits, MEB: methanolic extract of black fruits

\section{Total sugar content}

The total sugar content as indicated in Table 1, decreased significantly as maturity progress $(\mathrm{p}<0.05)$, from 5.65 for immature fruit to $3.33 \mathrm{mg} / 100$ gof dry powder, for mature fruit. These results were in accordance with reports previously published by Trapani et al. (2015), who studied the evolution of sugar contents during olive fruit ripening and found that sugars content kinetic decreased during the progressing maturity of fruits and indicate that there is an opposite relationship between oil and sugar contents; the oil content showed an upward trend, while the sugar content showed an opposite behavior with a downward trend. On the other hand, it is well known that sugars are precursors of oil biosynthesis, and they provide energy for metabolic changes, and generate secondary metabolites that cause the specific flavor of the final product (Rallo et al., 2018). However, studies of other non-oleaginous fruits such as cherry fruit, star apple fruit, Cudrania tricuspidata and blackberry fruits have shown increasing sugar content during ripening (Tosun et al., 2008; Mahmood et al., 2013; Teribia et al., 2016; Williams and Benkeblia, 2018).

\section{Mineral composition}

The average values of the ash content of immature and mature lentisk fruits were given in Table 1 . The ash content represents the total amount of mineral salts present in the fruit. According to the results shown in Table 1, immature fruits are richer in ash content compared to mature fruits, with $3.68 \pm 0.017 \%$ and $2.98 \pm 0.169 \%$, respectively. In a study investigating the effects of maturation stage on cherry fruit, Mahmood et al. (2013) indicated that as maturity progressed, ash contents decreased significantly. Similarly, in literature, Elgŭn et al. (1990) indicated that the ash content declined as the corn ripens. In other studies, investigating the changes in the functional constituents of firiks at different maturation stages, it was shown that ash contents of firik samples decreased with increasing maturation stages. A plausible explanation proposed in this study, suggests that the decrease in the percentage of ashes and proteins is due to the accumulation of nutritional components in the kernel during the maturation period (Özkaya et al., 2018).

The potassium $(\mathrm{K})$ content of lentisk fruits was higher than the amounts of other minerals, such as $\mathrm{Ca}, \mathrm{Mg}$ and $\mathrm{Na}$ (Table 5). This finding is agree with those obtained by Aouinti $e t$ al. (2013), who show that $P$. lentiscus fruits have a high potassium accumulation value compared to other minerals. In other study investigating the chemical composition of lentisk fruit oil, Dhifi et al. (2013) highlighted that $\mathrm{Na}$ is the most abundant mineral content in mature seeds, following by $\mathrm{K}, \mathrm{Ca}, \mathrm{Mg}, \mathrm{Fe}$ and $\mathrm{Cu}$. The variation in mineral content differs depending on the species and the environment's influence (Seraglio et al, 2017).

The data indicated that Sodium $(\mathrm{Na})$ and Potassium (K) levels decreased significantly from the immature stage to the mature stage, while Magnesium $(\mathrm{Mg}$ ) and Calcium (Ca) contents recorded the highest levels at the mature stage.

Significant differences of the accumulation of mineral elements were found between immature and mature fruits $(p<0.05)$. Sodium content decreased significantly from red fruit stage to black fruits stage from 323.2 to $114.9 \mathrm{mg} / \mathrm{kg}$, respectively, similar to the trend observed for potassium content, whereas Potassium was the predominant mineral with contents of $1,3866.6 \mathrm{mg} / \mathrm{kg}$ for unripe fruits and $1,3075 \mathrm{mg} / \mathrm{kg}$ for ripe fruits. As shown by Loué (1979), in his study of interaction between potassium $(\mathrm{K})$ and sodium $(\mathrm{Na})$ in plants, Sodium is not considered a strictly essential element for the growth of plants, although, it is a secondary element necessary for certain plants. Absorption of sodium by the plant is greatly reduced in the presence of relatively low concentrations of potassium (which plays a protective role), while potassium (K) uptake by the plant is generally very little influenced by relatively high sodium concentrations. Potassium is critical to the performance of many of the plant's enzymatic functions, and controls the metabolism of superior plants, which eventually affects the levels of metabolites (Wang et al., 2013). 
844

Table 5. Mineral compositions of immature and mature $P$. lentiscus fruit samples

\begin{tabular}{|c|c|c|c|c|c|c|}
\hline \multirow{3}{*}{ Analysis } & & \multicolumn{2}{|c|}{ Immature fruits } & \multicolumn{2}{|c|}{ Mature fruits } & \multirow{3}{*}{$\mathrm{p}$} \\
\hline & & $\begin{array}{l}\text { Means } \\
(\mathrm{mg} / \mathrm{kg})\end{array}$ & $\pm \mathrm{SD}$ & $\begin{array}{c}\text { Means } \\
(\mathrm{mg} / \mathrm{kg})\end{array}$ & $\pm \mathrm{SD}$ & \\
\hline & \multicolumn{5}{|c|}{ Macro minerals } & \\
\hline \multirow{4}{*}{ 交 } & $\mathrm{Na}$ & $323.25^{a}$ & 2.83 & $114.96^{b}$ & 0.58 & $<0.001$ \\
\hline & $\mathrm{K}$ & $13866.66^{\mathrm{a}}$ & 31.45 & $13075^{b}$ & 141.97 & $<0.05$ \\
\hline & $\mathrm{Mg}$ & $617.5^{\mathrm{b}}$ & 2.63 & $734.7^{\mathrm{a}}$ & 9.25 & $<0.01$ \\
\hline & $\mathrm{Ca}$ & $1653.58^{\mathrm{b}}$ & 4.36 & $2759.66^{a}$ & 14.22 & \multirow[t]{2}{*}{$<0.001$} \\
\hline \multirow{12}{*}{$\begin{array}{l}\sum_{i=1}^{n} \\
\underline{\tilde{U}}\end{array}$} & \multicolumn{5}{|c|}{ Micro minerals } & \\
\hline & $\mathrm{Fe}$ & $34.22^{\mathrm{a}}$ & 0.70 & $22.25^{b}$ & 0.43 & $<0.001$ \\
\hline & $\mathrm{Mn}$ & $1.92^{\mathrm{b}}$ & 0.01 & $4.47^{\mathrm{a}}$ & 0.026 & $<0.001$ \\
\hline & $\mathrm{Zn}$ & $5.12^{b}$ & 0.02 & $7.88^{a}$ & 0.065 & $<0.001$ \\
\hline & $\mathrm{Cu}$ & $4.41^{\mathrm{b}}$ & 0.02 & $5.15^{\mathrm{a}}$ & 0.03 & $<0.01$ \\
\hline & \multicolumn{6}{|l|}{ Heavy metals } \\
\hline & $\mathrm{Cr}$ & $0.167^{a}$ & 0.0026 & $0.09^{\mathrm{b}}$ & 0.003 & $<0.01$ \\
\hline & $\mathrm{Ni}$ & $0.55^{b}$ & 0.052 & $0.78^{a}$ & 0.01 & $<0.05$ \\
\hline & Co & $0.021^{\mathrm{b}}$ & 0.002 & $0.032^{\mathrm{a}}$ & 0.002 & $<0.05$ \\
\hline & $\mathrm{Cd}$ & $0.0036^{b}$ & 0.0002 & $0.0065^{\mathrm{a}}$ & 0.00026 & $<0.001$ \\
\hline & As & $0.015^{b}$ & 0.0017 & $0.019^{\mathrm{a}}$ & 0.002 & $<0.05$ \\
\hline & $\mathrm{Pb}$ & $0.148^{\mathrm{b}}$ & 0.002 & $\mathrm{a}$ & 0.001 & $<0.01$ \\
\hline
\end{tabular}

AAS: atomic absorption spectrometry, ICP-MS: inductively coupled plasma-mass spectrometry; SD: standard deviation; a-b: different letters indicate differences between means in the same row according to Tukey test at $\mathrm{p}<0.05$.

The highest calcium content was found in the mature fruits $(2,759.6 \mathrm{mg} / \mathrm{kg})$ followed by immature fruit $(1,653.5$ $\mathrm{mg} / \mathrm{kg}$ ). Calcium is important for the building of bones and teeth (Vicente et al., 2009). In plants, it is typically linked to pectic substances and is thought to have a strong effect on the rheological characteristics of the cell wall and, therefore, on the texture of fruits and vegetables (Rose et al., 2003; Vicente et al., 2009). It has been also associated with regulation of the fruit ripening process and postharvest storage life (Ferguson, 1984). Previous data on the importance of calcium in plant growth prove their high rate of accumulation in mature $P$. lentiscus fruits.

Magnesium (Mg), recorded a high level of accumulation at mature stage with $734.7 \mathrm{mg} / \mathrm{kg}$, against $617.5 \mathrm{mg} / \mathrm{kg}$ at immature stage, as shown in Table 5. Mg plays an essential role in protein synthesis; it activates several enzymes (more than 100). In plants, $\mathrm{Mg}$ is a component of the chlorophyll molecule that has a fixed magnesium central atom non dissociable (Vicente $e t$ al., 2009). It is suggested by Khader and Rama (2003) that the increase in magnesium contents at the maturity stage may have been due to existing of unfixed $\mathrm{Mg}$ ions that accumulate in fruits with age.

The changes of these mineral contents throughout the ripening differ according to each fruit species, In a study investigating the nutritional potential of myrtaceae fruits during ripening, Seraglio et al. (2017) highlighted that the maturity influenced mineral contents of the fruits while higher values of calcium and potassium were found in the ripe stage and no significant difference were obtained for magnesium concentration throughout the ripening period. Although, in another study about the different changes during ripening of blackberry fruits, Tosun et al. (2008) indicate that $\mathrm{K}$ and $\mathrm{Ca}$ contents exhibited moderate changes, whereas $\mathrm{Mg}$ levels decreased in the ripe mature stage.
Results obtained by an Inductively Coupled PlasmaMass Spectrometry (ICP-MS); method has been employed for the determination of the trace mineral contents of lentisk fruit at two maturity stages, are listed in Table 5.

The data indicated that the concentration of Manganese $(\mathrm{Mn})$, zinc $(\mathrm{Zn})$, copper $(\mathrm{Cu})$ increased as maturity progression, while iron $(\mathrm{Fe})$ level decreased in mature fruits, whereas the heavy metals as Chromium (Cr), Nickel (Ni), Cobalt (Co), Cadmium (Cd), Arsenic (As) and lead (Pb), are found in trace amounts.

Iron content ranged from $22.25 \mathrm{mg} / \mathrm{kg}$ for mature fruit to $34.22 \mathrm{mg} / \mathrm{kg}$ for immature fruits, this interval of concentration could be explained by the decrease of plant chlorophyll levels and the increase of anthocyanin content during ripening stage as shown in our previous data where suggesting that anthocyanin level increased in black fruit stage. According to Vicente et al. (2009), there is a strong correlation between iron level and chlorophyll content. Thus, insufficient iron intake leads to a disruption of chlorophyll development. Since Fe is stored in plastids in the phytoferritin form, which is comparable to the ferritin in animal cells. These findings agree with those reported by Williams and benkeblia (2018). It was also indicated that iron $(\mathrm{Fe})$ deficiency increased total phenolic content, this phenomenon has been observed in previous study on grape Berry, strawberry and lemon juice (Shi et al., 2018).

Manganese (Mn) concentration increased approximately by four times to $4.47 \mathrm{mg} / \mathrm{kg}$, in the mature fruit (Table 5), Mn is a key component of enzyme systems (Vicente et al., 2009). As suggested by Lopez et al. (2008), it may be used for the ripe olives as catalytic compound during the oxidation process. Manganese $(\mathrm{Mn})$ oxides considered biogenic in origin within natural systems, they are the only oxidants of $\mathrm{Cr}$ (Tang et al., 2014). Therefore, the high level of $\mathrm{Mn}$ in the mature stage as shown in this study was very 
effective for the degradation of $\mathrm{Cr}$ uptaked by the plant. This explains the decrease of chromure element at the mature stage of $P$. lentiscus fruit from 0.167 to $0.090 \mathrm{mg} / \mathrm{kg}$.

Znic is pervasive microelements which serve to activate a number of plant cell enzymes (Vicente et al., 2009). As shown in Table $5, \mathrm{Zn}$ concentrations were found to be higher in the mature fruit $(7.88 \mathrm{mg} / \mathrm{kg})$ than in red fruit $(5.12 \mathrm{mg} / \mathrm{kg})$. This finding is agree whit the result of Tosun et al. ( 2008) who reported that $\mathrm{Zn}$ content in blackberry fruits increased from the red fruit stage to ripe stage.

It was also observed that the copper $(\mathrm{Cu})$ level of black fruits was higher than those of red fruits. In fact, copper is a constituent element of the catalytic oxidation of phenols in aerobic conditions, which give rise to ortho-quinones, biphenols or benzoxepines (Esguerra et al., 2014). It follows that the copper content in lentisk fruits is positively correlated with the phenolic content.

As shown in Table 5, content of heavy metals such as lead and cadmium increased significantly during maturation, this data can be attributed to many causes, including environmental pollution and pesticide traces. However, their accumulation remains lower than the limit values for $\mathrm{Cd}$ and $\mathrm{Pb}$ proposed by $\mathrm{HO}$ (1999), which ranged from 0.3 to $10 \mathrm{mg} / \mathrm{kg}$. Therefore, the presence of heavy metals at very low concentrations does not affect the nutritional quality of the fruit.

\section{Conclusions}

The results of our work show that the mature fruits of Pistacia lentiscus L. had a high content of phytoconstituents and nutrients which reflects their high nutritional value. So, qualitative analysis of hexane extract by GC-MS reveled, in addition to its composition in volatile compounds such as mono and polyunsaturated fatty acids in the immature stage, fixed oil of lentisk fruits is richer in volatile compounds at maturity thanks to the synthesis of new molecules such as squalene, $\alpha$-Tocopherol acetate, reflecting its high nutritional value. Total sugar decreased, while all secondary metabolite tested reached their highest values in the mature stage. In addition, a direct relationship between metabolites and antioxidant activity and color has been reported. On the other hand, analysis of macro and microelements indicates a high content for most minerals such as calcium, magnesium, zinc and copper in mature fruits; however, a high concentration of iron was indicated in the immature fruits.

In addition, our results confirm the influence of $P$. lentiscus fruits maturity stage on their fixed oils chemical composition, phenolic compounds level, sugar content, antioxidant activity and mineral composition.

Furthermore, they provide valuable information on the biosynthesis and accumulation of $P$. lentiscus bioactive compounds which determinate the best harvesting period for the studied species and in order to benefit from the nutritional value of its fixed oil or whole fruit, which can also contribute to the better use as well as to the improvement of the value of this non-timber forest product, particularly in the pharmaceutical and nutritional fields.

\section{Conflicts of interest}

The authors declare that there are no conflicts of interest related to this article.

\section{References}

Akond ASM, Golam Masum, Khandaker L, Berthold J, Gates L, Peters K, ... Hossain K (2011). Anthocyanin, total polyphenols and antioxidant activity of common bean. American Journal of Food Technology 6(5):385-394.

Aouinti F, Zidane H, Tahri M, Wathelet Jean P, El Bachiri A (2014). Chemical composition, mineral contents and antioxidant activity of fruits of Pistacia lentiscus L. from Eastern Morocco. Journal of Materials andEnvironmental Science 5(1):199-206.

Bampouli A, Kyriakopoulou K, Papaefstathiou G, Louli V, Aligiannis N, Magoulas K, Krokida M (2015). Evaluation of total antioxidant potential of Pistacia lentiscus var. chia leaves extracts using UHPLCHRMS. Journal of FoodEngineering 167:25-31.

Bozorgi M, MemarianiZ, Mobli M, SalehiSurmaghi MH,Shams-Ardekani MR, Rahimi R (2013). Five Pistacia species (P. vera, P. atlantica, P. terebinthus, P. khinjuk, and P. lentiscus): A review of their traditional uses, phytochemistry, and pharmacology. The Scientific World Journal 219815.

Charef M, Yousfi M, Saidi M, Stocker P (2008). Determination of the fatty acid composition of acorn (Quercus), Pistacia lentiscus seeds growing in Algeria. Journal of the American Oil Chemists' Society 85(10):921-924.

Chaves-Silva S, Santos AL dos, Chalfun-Júnior A, Zhao J, Peres LEP, Benedito VA (2018). Understanding the genetic regulation of anthocyanin biosynthesis in plants - tools for breeding purple varieties of fruits and vegetables. Phytochemistry 153:11-27.

Daffodil ED, Uthayakumari FK, Mohan VR (2012). GC-MS determination of bioactive compounds of Curculigo orchioides gaertn. Science Research Reporter 2(3):198-201.

Dhifi W, Jelali N, Chaabani E, Beji M, Fatnassi S, OmriS, MnifW (2013). Chemical composition of Lentisk (Pistacia lentiscus L.) seed oil. African Journal of Agricultural Research 8(16):1395-1400.

Djenane D, Yangüela J, Montañés L, Djerbal M, Roncalés P (2011). Antimicrobial activity of Pistacia lentiscus and Satureja montana essential oils against Listeria monocytogenes CECT 935 using laboratory media: Efficacy and synergistic potential in minced beef. Food Control 22(7):1046-1053.

Dubois M, Gilles KA, Hamilton JK, Rebers PA, Smith F (1956). Colorimetric method for determination of sugars and related substances. Analytical Chemistry 28(3):350-356.

Elgŭn A, Ertugay Z, Certel M (1990). Corn Bulgur: Effects of corn maturation stage and cooking form on bulgur-making parameters and physical and chemical properties of Bulgur products. Cereal Chemistry 67(l):1-6.

Esguerra KVN, Fall Y, Petitjean L, LumbJP(2014). Controlling the catalytic aerobic oxidation of phenols. Journal of the American Chemical Society 136(21):7662-7668. 
846

Ferguson IB (1984). Calcium in plant senescence and fruit ripening, Plant, Cell andEnvironment 7(6):477-489.

French MA, Sundram K, Clandinin MT (2002). Cholesterolaemic effect of palmitic acid in relation to other dietary fatty acids. Asia Pacific Journal ofClinical Nutrition 11(Suppl.7):S401-407.

Giusti MM, Wrolstad RE (2001). Characterization and measurement of anthocyanins by UV-Visible spectroscopy. In: Wrostald RE (Ed), Current Protocols in Food Analytical Chemistry. New York: John Wileyand Sons.

Hataminia F, Farhadian N, Karimi M, Ebrahimi M (2018). A novel method for squalene extraction from pumpkin seed oil using magnetic nanoparticles and exploring the inhibition effect of extracted squalene on angiogenesis property. Journal of the Taiwan Institute of Chemical Engineers 91:1-9.

He J, Giusti MM (2010). Anthocyanins: natural colorants with healthpromoting properties. Annual Review of Food Science and Technology 1(1):163-187.

Hosni K,Jemli M, Dziri S, M'rabet Y,Ennigrou A, Sghaier A,... Sebei H (2011). Changes in phytochemical, antimicrobial and free radical scavenging activities of the Peruvian pepper tree (Schinus molle L.) as influenced by fruit maturation. Industrial Crops and Products. 34(3):1622-1628.

Iserin P, Masson M, Restellini J, Ybert E, De Laage de Meux A, Moulard F, ... Vican P (2001). Larousse des plantes médicinales: identification,

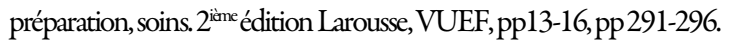

Khader V, Rama S (2003). Effect of maturity on macromineral content of selected leafy vegetables. Asia Pacific Journal of Clinical Nutrition 12(1):45-49.

Llorens Molina JA, Vacas González S, Sabater Martínez J (2015). Essential oil composition of leaves of Pistacia lentiscus L. growing wild in Valencia (Spain).Natural Volatiles and Essential Oils 2(4):17-26.

Longo L, Scardino A, Vasapollo G (2007). Identification and quantification of anthocyanins in the berries of Pistacia lentiscus L, Phillyrea latifolia L. and Rubia peregrina L. Innovative Food Science \& Emerging Technologies 8(3):360-364.

López A, García P, Garrido A (2008). Multivariate characterization of table olives according to their mineral nutrient composition. Food Chemistry 106(1):369-378.

Loué A (1979). Interaction du potassium avec d'autres facteurs de croissance. Interaction de $\mathrm{K}$ avec les autres éléments nutritifs. Au Service de l'Agriculture. Dossier K2O 15:1-32.

Mahmood T, Anwar F, Bhatti IA, Iqbal T (2013). Effect of maturity on proximate composition, phenolics and antioxidant attributes of cherry fruit. Pakistan Journal of Botany 45(3):909-914.

Martinez KB, Mackert JD, McIntosh MK (2017). Polyphenols and intestinal health. Nutrition and Functional Foods for Healthy Aging 191-210.

McGuire RG (1992). Reporting of objective color measurements. HortScience 27(12):12541255.

Moreira-Araujo RSDR, Sampaio GR, Soares RAM, da Silva CP, Araujo MADM, Areas JAG (2018).Identification and quantification of phenolic compounds and antioxidant activity in cowpeas of 'Brs Xiquexique' cultivar. Revista Caatinga 31(1):209-216.
Nahida SH Ansari, Siddiqui AN (2012). Pistacia lentiscus: A review on phytochemistry and pharmacological properties. International Journal of Pharmacy and Pharmaceutical Sciences 4(4):16-20.

Nobre CB, Sousa EO, Camilo CJ, Machado JF, Silva JMFL, Filho JR,... Costa JGM (2018). Antioxidative effect and phytochemical profile of natural products from the fruits of "babaçu" (Orbignia speciose) and "buriti" (Mauritia flexuosa). Food and Chemical Toxicology 121:423429.

Özkaya B, Turksoy S, Özkaya H, Baumgartner B, Özkeser İ, Köksel H (2018). Changes in the functional constituents and phytic acid contents of firiks produced from wheats at different maturation stages. Food Chemistry 246:150-155.

Pereira GG, Detoni CB, da Silva TL, Colomé LM, Pohlmann AR, Guterres SS (2015). $\alpha$-Tocopherol acetate-loaded chitosan microparticles: Stability during spray drying process, photostability and swelling evaluation. Journal of Drug Delivery Science and Technology 30:220-224.

Rallo L, Díez CM, Morales-Sillero A, Miho H, Priego-Capote F, Rallo P (2018). Quality of olives: A focus on agricultural preharvest factors. Scientia Horticulturae 233:491-509.

Rombaut N (2013). Etude comparative de trois procédés d'extraction d'huile: application aux graines de lin et aux pépins de raisin ; aspects qualitatifs et quantitatifs. Thèse de Doctorat, Université de Technologie. Compiègne, Paris, pp 252.

Rose JKC, Catala C, Gonzalez-Carranza ZH, Roberts JA (2003). Cell wall disassembly. Annual Plant Reviews 8:264324.

Rubinskiene M, Viskelis P, Jasutiene I, Duchovskis P, Bobinas C (2006). Changes in biologically active constituents during ripening in black currants.Journal of Fruit and Ornamental Plant Research 14:237-246.

Saleem M (2009). Lupeol, a novel anti-inflammatory and anti-cancer dietary triterpene. Cancer Letters 285(2):109-115.

Sanchez-Moreno C (2002). Review: Methods used to evaluate the free radical scavenging activity in food and biological systems. Food Science and Technology International 8(3):121-137.

Seraglio SKT, Schulz M, Nehring P, Betta FD, Valese AC, Daguer H, ... Costa ACO (2017). Nutritional and bioactive potential of Myrtaceae fruits during ripening. Food Chemistry 239:649-656.

Serrano M, Zapata P, Pretel MT, Almansa MS, Botella MA, Amorós A (2003). Changes in organic acid and sugars levels during ripening of five loquat (Eriobotrya japonica Lindl.) cultivars. Options Mediterraneennes 58:157-160.

Shi P, Song C, Chen H, Duan B, Zhang Z, Meng J (2018). Foliar applications of iron promote flavonoids accumulation in grape berry of Vitis vinifera cv. 'Merlot' grown in the iron deficiency soil. Food Chemistry 253:164170.

Shin GR, Lee S, Do SG, Shin E, Lee CH (2015). Maturity stage-specific metabolite profiling of Cudrania tricuspidata and its correlation with antioxidant activity. Industrial Crops and Products 70:322-331.

Singleton VL, Rossi JA (1965). Colorimetry of total phenolics with phosphomolybdic phosphotungstic acid reagents. American Journal Enology and Viticulture 16(3):144-158.

Skrovankova S, Sumczynski D, Mlcek J, Jurikova T, Sochor J (2015). 
Bioactive compounds and antioxidant activity in different types of berries. International Journal of Molecular Sciences 16(10):2467324706.

Tang Y, Webb SM, Estes ER, Hansel CM (2014). Chromium (III) oxidation by biogenic manganese oxides with varying structural ripening Environmental Science: Processes and Impacts 16(9):2127-2136.

Teribia N, Tijero V, Munné-Bosch S (2016). Linking hormonal profiles with variations in sugar and anthocyanin contents during the natural development and ripening of sweet cherries. New Biotechnology 33(6):824-833.

Tosun I, Ustun NS, Tekguler B (2008). Physical and chemical changes during ripeningof blackberry fruits. Scientia Agricola 65(1):87-90.

Trabelsi H, Cherif OA, Sakouhi F et al. (2012). Total lipid content, fatty acids and 4-desmethylsterols accumulation in developing fruit of Pistacia lentiscus L. growingwild in Tunisia. Food Chemistry 131(2): 434440.

Trapani S, Migliorini M, Cherubini C, Cecchi L, Canuti V, Fia G, Zanoni B (2016). Direct quantitative indices for ripening of olive oil fruits to predict harvest time. European Journal of Lipid Science and Technology 118(8):1202-1212.

Vicente AR, Manganaris GA, Sozzi GO, Crisosto CH (2009). Nutritional quality of fruits and vegetables. In: Florkowski WJ, Shewfelt RL, Brueckner B, Prussia SE (Eds). Postharvest Handling: A Systems Approach. Elsevier Incpp 58-93.
WangM, ZhengQ, Shen Q, Guo S (2013). The critical role of potassium in plant stress response. International Journal of Molecular Sciences 14(4):7370-7390.

WHO (1999). WHO Monographs on Selected Medicinal Plants, vol. 1 World Health Organization, Geneva, Switzerland.

Williams RS, Benkeblia N (2018). Biochemical and physiological changes of star apple fruit (Chrysophyllum cainito) during different "on plant" maturation and ripening stages. Scientia Horticulturae 236:36-42.

Xiao H,Li A,Li M, Sun Y, Tu K, WangS, Pan L(2018). Qualityassessment and discrimination of intact white and red grapes from Vitis vinifera $\mathrm{L}$. at five ripening stages by visible and near-infrared spectroscopy. Scientia Horticulturae 233:99-107.

Yen GC, Chen HY (1995). Antioxidant activity of various tea extracts in relation to their antimutagenicity. Journal of Agricultural and Food Chemistry 43(1):27-32.

Zekeya N, Chacha M, Shahada F, Kidukuli A (2014). Analysis of phytochemical composition of Bersama abyssinica by gas chromatography mass spectrometry. Journal of Pharmacognosy and Phytochemistry3(4):246-252. 